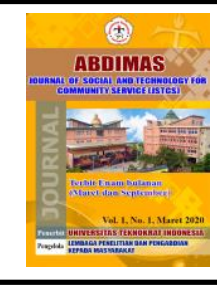

\title{
SISTEM INFORMASI MANAJEMEN DANA DONATUR BERBASIS WEB PADA PANTI ASUHAN YATIM MADANI
}

\author{
Sampurna Dadi Riskiono ${ }^{1}$, Fikri Hamidy ${ }^{2}$, Tami Ulfia ${ }^{3}$ \\ Universitas Teknokrat Indonesia ${ }^{1,2,3}$
}

Email : sampoerna.go@gmail.com ${ }^{1}$, $\underline{\text { ikrihamidy @ teknokrat.ac.id }}$

\begin{abstract}
Received: January 18, 2020
Accepted: February 16, 2020

Abstract

Yatim Madani Orphanage does not yet have an integrated information system to support its data processing, for example data management for orphans and assistance. The process that has been carried out so far is still manual, such as recording data in books, and delivery of fund information, the institution only tells when there are donors visiting the Orphanage. From this research a websitebased Donor Fund Management Information System is designed using crowdfunding method, with a donation site model that disseminates donation information through social media making it easier to make donation projects and publish funds needed
\end{abstract}

Published : March 15, 2020

Keywords: Blackbox, Crowdfunding, Orphanage, Prototype.

\begin{abstract}
Abstrak
Panti Asuhan Yatim Madani belum memiliki Sistem Informasi yang terintegrasi untuk mendukung proses pengolahan datanya, misalnya pengelolaan data anak panti dan bantuan. Proses selama ini yang dilakukan masih manual, seperti pencatatan data di buku, dan penyampaian informasi dana, pihak panti hanya memberitahu saat ada donatur yang berkunjung ke Panti Asuhan. Dari Penelitian ini dirancang suatu Sistem Informasi Manajemen Dana Donatur berbasis website menggunakan metode crowdfunding, dengan model situs donasi yang penyebaran informasi donasi melalui media sosial sehingga memudahkan untuk membuat proyek donasi dan mempublikasikan dana yang dibutuhkan.
\end{abstract}

Kata Kunci: Blackbox, Crowdfunding, Panti Asuhan, Prototype.

\section{PENDAHULUAN}

Teknologi Sistem Informasi yang sangat pesat mendorong masyarakat menggunakan teknologi untuk dapat berkembang. Saat ini teknologi website tidak hanya digunakan sebagai alat komunikasi, tetapi juga digunakan sebagai sarana untuk mempermudah penggunanya dalam kehidupan sehari-hari. Hal tersebut terjadi karena teknologi website terdapat fasilitas seperti hak akses internet yang dapat digunakan dimana saja dan kapan saja untuk melihat dan mengolah berbagai data dan informasi dalam sebuah organisasi atau perusahaan. Sistem pengolahan data tentunya sangat diperlukan bagi suatu organisasi, hal ini dikarenakan sistem tersebut terdiri dari sub-sub yang saling berkaitan untuk mengolah data yang berkaitan dengan masalah dan membantu organisasi dalam pengambilan keputusan (Kumala, Borman \& Prasetyawan, 2018).

Akan tetapi tingginya pemanfaatan IT ini masih belum menjangkau instansi sosial yang jarang mengikuti perkembangan dunia IT seperti instansi yang lain. Salah satu instansi sosial yang belum memiliki Sistem Informasi Manajemen, yaitu Panti Asuhan Yatim Madani. Yang berdiri dari tahun 2015, serta memiliki anak asuh sebanyak 25 orang yang terdiri dari 10 orang anak laki-laki dan 15 anak perempuan, sejak didirikan Panti Asuhan Yatim Madani yang beralamatkan Jl.Kelinci No.29, Kedaton Bandar Lampung belum memiliki Sistem Informasi yang terintegrasi.

Dalam pendataan anak panti, dan bantuan di Panti Asuhan Yatim Madani masih berupa catatan di buku. Dan tentang penyampaian informasi dana, pihak panti hanya memberitahu saat ada donatur yang berkunjung ke panti. Sehingga informasi tentang penggunaan dana donatur masih kurang tersampaikan dengan baik. Sedangkan dalam memperkenalkan Panti Asuhan Yatim Madani biasanya pengelola panti memperkenalkan saat ada kajian rutin, memasang iklan plang di pinggir jalan yang mendekati lokasi Panti Asuhan Yatim Madani, dan dalam keadaan darurat pengelola panti membuat proposal kepada para donatur untuk menyampaikan apa saja yang sedang dibutuhkan saat ini. Hal ini tentu tidak maksimal untuk dapat mengelola sebuah panti asuhan. 
Untuk mengatasi permasalahan tersebut dapat diselesaikan dengan adanya metode Crowdfunding seperti yang dilakukan oleh Deni Fadjri, I.P. (2019) dalam penelitiannya yang berjudul Rancang Bangun Sistem Informasi Pengumpulan dana panti asuhan menggunakan metode Crowfunding dengan model situs donasi. Kendala yang terjadi penyampaian informasi tentang kebutuhan dana atau biaya bagi panti asuhan seperti dana infrastruktur panti asuhan dana insidential dan dana kebutuhan panti asuhan informasi secara umum tidak disebarkan. Sehingga setiap orang atau donatur yang berkunjung saja yang mengetahui informasi tersebut. Untuk mengatasi kendala tersebut dibuatlah website dengan menggunakan metode crowdfunding, dan permodelan OO (Object Oriented) (Pressman, 2010), yang melakukan pendekatan terhadap masalah dari perspektif obyek.

Crowdfunding adalah suatu praktik penggalangan dana untuk berbagai jenis usaha, baik berupa ide produk, bisnis atau kegiataan yang dananya diperoleh dari sumbangan masyarakat umum atau kelompok. Manfaat yang dirasakan setelah dibangunnya sistem informasi pengumpulan dana panti asuhan menggunakan metode crowdfunding dapat memenuhi kebutuhan panti asuhan untuk membuat proyek donasi dan mempublikasikan dana yang dibutuhkan.

Penelitian lainnya yang pernah dilakukan oleh Alghofari, A, (2013) adalah membuat Sistem Informasi Manajemen Panti Asuhan Yatim PKU Muhammadiyah Cabang Blimbing. Untuk mengatasi kendala yang terjadi di Panti Asuhan Yatim PKU Muhammadiyah Cabang Blimbing dibuatlah Sistem Informasi Manajemen Panti Asuhan berbasis website. Sehingga pengelolaan dana donatur dan pengenalan Panti Asuhan terintegrasi dengan baik. Pengelolaan penerimaan dana donasi juga pernah diusulkan oleh Ibrahim (2017), sistem yang dibangun mamapu membantu pihak panti dalam mengelola dana donasi dari para donatur. Innayati (2017) juga pernah mengembangkan sistem manajemen dan kepengasuhan panti agar pengelola panti dapat mengefisiensi pekerjaan.

Dengan adanya metode Crowdfunding membantu pihak Panti Asuhan Yatim Madani dalam memperkenalkan Panti Asuhan, Melalui media sosial, Facebook Twiter, Whatsapp, Line dan Google ${ }^{++}$.dan implemetasi menggunkan Website dapat membantu mengelola Panti Asuhan Yatim Madani, dalam pengelolaan dana donatur. Serta menambahkan dalam pembangunan Sistem tentang pengelolaan data invetaris panti yang akan membantu pihak panti mengelola data inventaris mereka. Penelitian ini diharapkan dapat membantu Panti Asuhan Yatim Madani dalam mengolah dana donatur lebih baik, dan donatur tanpa harus terkendala oleh jarak dan waktu ketika mengakses informasi dana dan juga melakukan donasi di Panti Asuhan Yatim Madani.

\section{METODE PELAKSANAAN \\ Tempat dan Waktu}

Kegiatan ini dilaksanakan di Panti Asuhan Yatim Madani Bandar Lampung yang beralamatkan di Jl.Kelinci No.29, Kedaton Bandar Lampung. Kegiatan pengembangan sistem dimulai dari tahapan pengumpulan data yang dilaksanakan pada tanggal 01 Maret 2019.

\section{Khalayak Sasaran}

Sasaran kegiatan pengabdian yang mengembangkan sistem informasi manajemen ini adalah pengurus panti asuhan, donatur dan anak asuh sebanyak 25 orang yang terdiri dari 10 orang anak laki-laki dan 15 anak perempuan.

\section{Metode Pengabdian}

Mulai dari pengumpulan data yakni wawancara, observasi dan literatur dapat diketahui permasalahanpermasalahan yang ada pada proses pengelolaan donasi di Panti Asuhan Yatim Madani

\subsection{Pengumpulan Data}

1. Wawancara

Wawancara merupakan teknik pengumpulan data yang dilakukan melalui tatap muka dan tanya jawab langsung antara pengumpul data maupun peneliti terhadap nara sumber atau sumber data. Wawancara telah diakui sebagai teknik pengumpulan data/fakta (fact finding technique) yang penting dan banyak dilakukan dalam perancangan ataupun pengembangan sistem informasi

2. Observasi

Teknik yang pertama penulis lakukan adalah observasi atau survey langsung terhadap tempat penelitian. Teknik ini digunakan penulis dalam penelitian untuk mempelajari perilaku manusia, proses kerja, gejalagejala alam dan dilakukan pada responden yang tidak terlalu besar. 


\subsection{Rancangan Use Case}

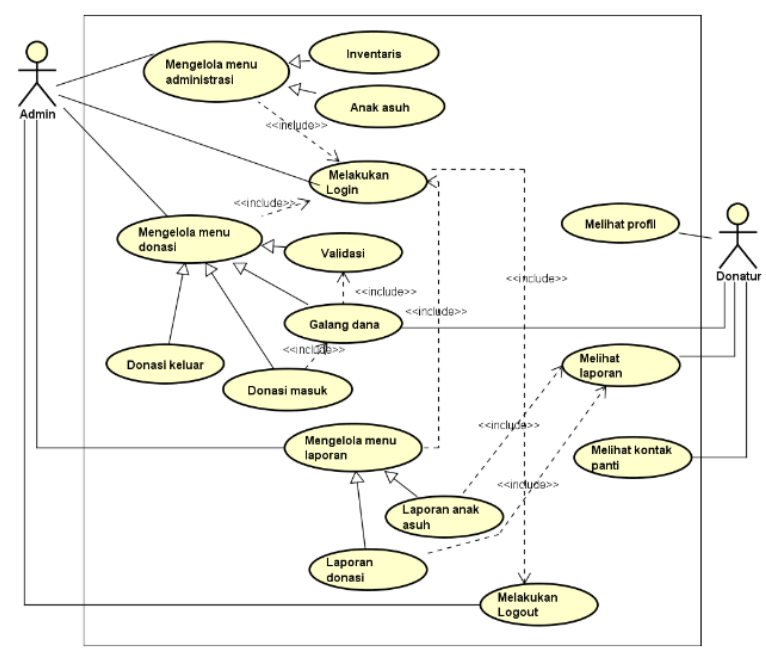

Gambar 3.1 Use Case Diagram

Keterangan aktor dari Use case diagram dapat dilihat pada tabel 1.

Tabel 1. Keterangan Aktor

\begin{tabular}{ll}
\hline \multicolumn{1}{c}{ Aktor } & \multicolumn{1}{c}{ Keterangan } \\
\hline Donatur & Merupakan orang yang memiliki hak akses untuk melihat profil dan kontak Panti \\
& Asuhan Yatim Madani, memberi donasi dan melihat laporan pada panti asuhan \\
& yatim madani \\
\hline Admin & Merupakan orang yang memiliki hak akses untuk login, logout, dapat mengelola \\
& data anak asuh, inventarisasi panti asuhan, galang dana, donasi masuk donasi \\
& keluar, laporan donasi masuk, donasi keluar, validasi pemberian donasi. \\
\hline
\end{tabular}

\section{HASIL DAN PEMBAHASAN \\ Implementasi Sistem}

Tahapan implementasi merupakan tahap transalasi desain yang telah dirancang ke dalam sebuah kode program, implementasi yang dilakukan meliputi implementasi rancangan antar muka (user interface) maka hasil rancangan adalah sebagai berikut.

1. Tampilan Awal

Form tampilan awal merupakan tampilan saat pertama kali pengguna sesudah menuliskan alamat situs web, hak akses dapat dilakukan oleh donatur dan admin, donatur dapat melihat profil Panti Asuhan, melakukan galang dana, melihat data anak asuh, laporan keungan dan kontak sedangkan admin dapat melakukan login untuk mengelola sistem tersebut. Berikut adalah form Tampilan awal yang dapat dilihat pada gambar 1 .

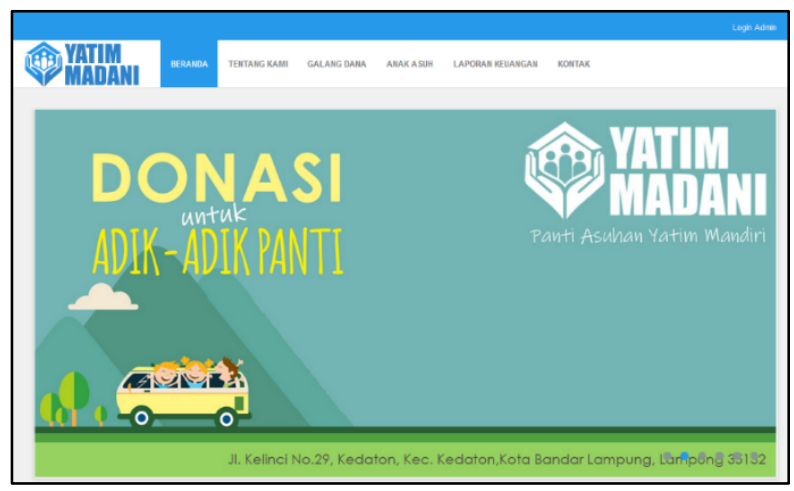


Gambar 1. Form Tampilan Awal

\section{Form Galang Dana}

Merupakan form yang menampilkan bagaimana cara donatur untuk menggalang dana ataupun donasi di Panti Asuhan Yatim Madani, donasi apa saja yang dituhkan, dana yang dibutuhkan, nominal dana yang sudah terkumpul, dapat dibagikan oleh donatur atau admin melalui media sosial seperti:facebook, twitter, whatsapp, line, google ++, dan terdapat No Rek Panti Asuhan untuk melakukan donasi. Berikut adalah Form Galang Dana yang dapat dilihat pada gambar 2.

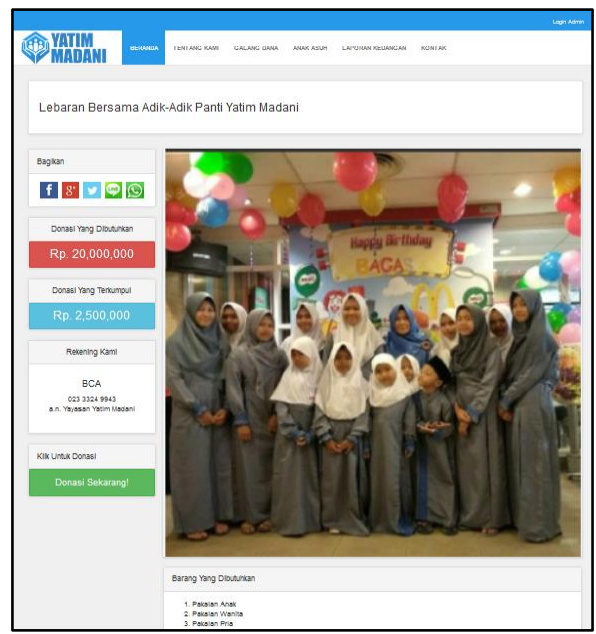

3. Form Menu Login Admin

Gambar 2. Form Galang Dana

Merupakan tampilan yang berfungsi untuk masuk kedalam sebuah Sistem yang hanya dilakukan oleh admin, pengguna (admin) diminta mengisi nama pengguna atau username dan kata sandi Berikut adalah form menu login yang dapat dilihat pada gambar 3 .

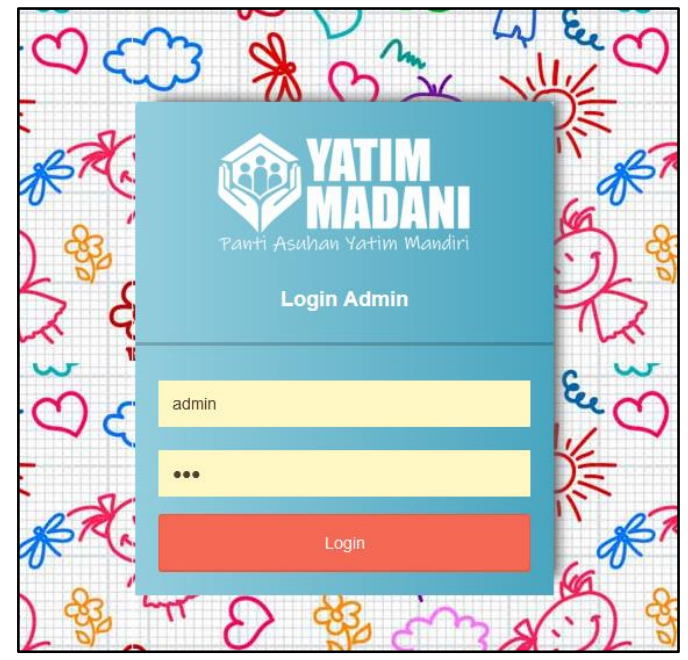

Gambar 3. Form Menu Login

4. Form Menu Utama Admin

Form menu utama admin merupakan tampilan yang berfungsi untuk mengelola menu-menu yang akan di akses oleh admin adapun hak akses yang dilakukan adalah mengelola semua menu, seperti menu administrasi yang terdiri dari data anak asuh, inventarisasi, menu donasi seperti donasi masuk, donasi keluar, validasi, 
galang dana dan menu Laporan yang terdiri dari laporan anak asuh dan donasi . Berikut adalah form menu utama admin yang dapat dilihat pada gambar 4.

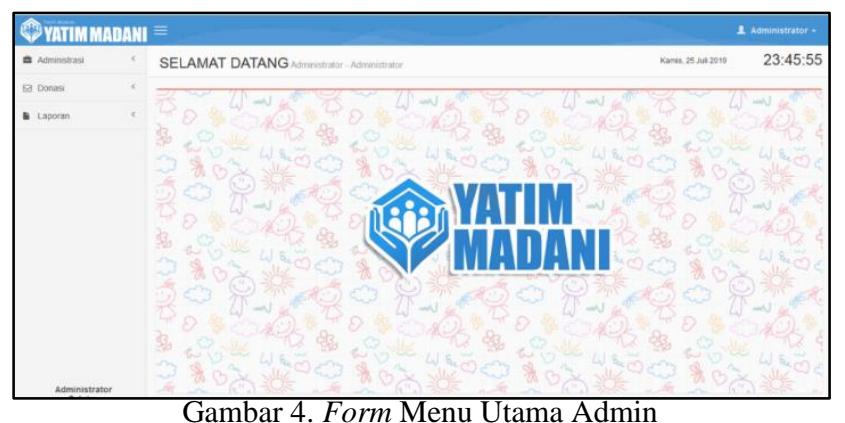

\section{Pengujian Sistem}

Pada tahap ini dilakukan pengujian sistem yang telah diimplementasikan menggunakan pengujian blackbox. Berikut merupakan hasil pengujian Sistem Informasi Manajemen Dana Donatur:

Tabel 2. Hasil Pengujian Blackbox

\begin{tabular}{lcc}
\hline Kategori & Frekuensi Jawaban & Responden \\
\hline Diterima & 123 & 3 \\
\hline Ditolak & 0 & 3 \\
\hline
\end{tabular}

Dengan adanya pengujian sistem tersebut, dapat diketahui bahwaa Sistem Informasi Manajemen Dana Donatur yang diuji oleh 3 responden yaitu: 2 orang tenaga pengajar di Universitas Teknokrat Indonesia dan 1 orang pengurus Panti Asuhan Yatim Madani. Dimana hasil pengujian dapat disimpulkan bahwa sistem informasi manajemen dana donatur layak digunakan, karena fungsi aplikasi dapat berjalan dengan tujuan yang diharapkan. Berdasarkan hasil perhitungan pengujian yang telah dilakukan didapati nilai $100 \%$ yang berarti bahawa sistem tersebut sangat baik atau layak untuk digunakan.

\section{KESIMPULAN}

Berdasarkan hasil penelitian, analisis serta perancangan yang penulis lakukan pada Panti Asuhan Yatim Madani dapat diambil kesimpulan sebagai berikut:

1. Sistem informasi Manajemen Dana Donatur berbasis web dapat membantu pengurus Panti Asuhan dalam pengolahan dana donasi, yang dilengkapi dengan fitur memasukkan donasi masuk dan donasi keluar kedalam sistem dan tersimpan di database, sehingga pengurus Panti Asuhan Yatim Madani dapat menjadi transparan kepada donatur tentang penyampaian donasi dan pemakaian dana bantuan.

2. Sistem informasi manajemen dana donatur ini dirancang dengan menggunakan bahasa pemrograman PHP, diolah dengan database MySql. Dan menggunakan metode Crowdfunding untuk mencari donatur dan menyebarkan informasi bantuan yang sedang di butuhkan, dengan cara membagikan informasi bantuan melalui media sosial, seperti Facebook, Google ${ }^{++}$, Twitter, Line dan Whatsapp.

3. Sistem informasi manajemen dana donatur berbasis web diuji menggunakan blacbox berdasarkan aspek functionality. Pada Aspek functionality telah diuji oleh pakar menunjukkan bahwa sistem dapat melakukan $100 \%$ fungsinya dengan benar, yang berarti bahwa sistem sangat baik dan sangat layak untuk digunakan.

\section{REFERENSI}

Alghofari, A. 2013. Sistem Informasi Manajemen Panti Asuhan Yatim PKU Muhammadiyah Cabang Blimbing. Simposium Nasional Teknologi Terapan, Hal 64-73, ISSN: 2339-028X.

Deni Fadjri, I. P. 2019. Rancang Bangun Sistem Informasi Pengumpulan Dana Panti Asuhan Menggunakan Metode Crowdfunding Dengan Model Situs Donasi. Jurnal Komputer Dan Aplikasi, hal 64-73 Vol 07, No. 01. 
Ibrahim Ikhsan Muhamad, S. D. 2017. Sistem Informasi Penerimaan Donasi (Studi Kasus: Yayasan Sahabat Yatim Madani. Jurnal Ilmu Pengetahuan Dan Teknologi Komputer, Vol.3.No. 1 ,E-ISSN:2527-4864.

Innayati Immah, F. H. 2017. Analisa Desain SIMPM-Sistem Informasi Manajemen Dan Kepengasuhan Panti Muhammadiyah Jawa Timur BerbasisWeb Menggunakan Metode Object Oriented Dan Iconic Process. Prosiding SENTIA-Politeknik Negeri Malang, Vol 9-ISSN: 2085-23457.

Kumala, Agustina Eka, Rohmat Indra Borman, Purwono Prasetyawan. 2018. Sistem Informasi Monitoring Perkembangan Sapi di Lokasi Uji Performance (Studi Kasus: Dinas Perternakan dan Kesehatan Hewan Provinsi Lampung). Jurnal Tekno Kompak, Vol. 12, No. 1, 2018.

Pressman, R.S. 2010, Pendekatan Praktisi Rekayasa Perangkat Lunak.Edisi 7 Yogyakarta: Penerbit Andi. Raharjo, B. I. 2012. Modul PemrogramanWEB, HTML,PHP\&MYSQL.Bandung: Modula Bandung. 